\title{
Research Perspectives on the Impact of Media on Children and Young Adults
}

\author{
Mirela Tolic, Zlatko Milisa \\ Department of Pedagogy, Faculty of Philosophy, University of Osijek, Osijek, Croatia
}

Email address:

mtolic@ffos.hr (M. Tolic), zmilisa@ffos.hr (Z. Milisa)

To cite this article:

Mirela Tolic, Zlatko Milisa. Research Perspectives on the Impact of Media on Children and Young Adults. Science Journal of Education. Vol. 3, No. 3, 2015, pp. 50-59. doi: 10.11648/j.sjedu.20150303.12

\begin{abstract}
This article in its theoretical as well as empirical part shows the research results which point to the fact that the new media change habits and values of young people and children. Under the spread of technical globalization patterns of behaviour, up-bringing, learning and preferences are being changed. Some research results point to the fact that the media are more and more turning into a source of manipulation and addiction, instead of being a source of information, education and entertainment. The phenomenon of the so called cyber space media culture is ever more present and carries multiple implications on consciousness and behaviour of young people and children. Communicational theoreticians, sociologists, media pedagogues and mediology experts agree with the thesis that social power is held by those who control information. Powerful corporations, using the media, are turning children into passive consumers, addicted to things and incapable to differentiate the authentic from the non-authentic reality. By erasing the boundaries between the real and the imagined these media become the means of ideology of seduction and, with the doctrine of radical moral relativism, turn homo sapienscommunicans into homo consumens, with especially negative implications of (such) media socialization on the up-bringing of children and young people.However, there are also positive examples listed in this dissertation concerning the use of new media in contemporary ways of learning and education. The article contains many research results and examples of disturbance of educational and communicational processes via entertainment industry, advertising fetishism, beauty cult, virtual reality etc.Media as the carriers of symbolic messages are the main analytical point in the empirical part of this work. This part of the article presents the research among 430 participants, among whom were 306 students of seventh and eighth grades, 92 parents and 42 teachers, from four primary schools in Zadar County and the County of Split-Dalmatia. The achieved results argue the given hypotheses through numerous indicators from the answers to the question of when and how the primary school children become the children of media. The analyses of the gained results converge with theoretical starting points of the article concerning the need to implement media education into school curriculum.
\end{abstract}

Keywords: Media Pedagogy, (Dis) Functional Role of the Media, Education vs. Manipulation, Prevention Projects, Media Competences

\section{Introduction}

Prominent scientists in the field mediology have common thesis that the media have three levels of individual involvement in educational and socio- communication process: the first level is related to the level of social integration, the second level is based on social communication (education, information through the media), and the third is focused on the cultural level (Baacke, 1997; Hugo, 2007; Moser, 2000). These three levels are divided into two main aspects: the structural aspect, which starts with the question of what the media should inform the process of education, (to prevent dysfunctional roles), and the second aspect relates to the method and aspect of information, answering the question: know how to live with the media. In this approach emphasizes the fact that modern media is suppressed once the primary agents of socialization of children and young people, primarily family and school. The problem is the fact that contemporary actors in education increasingly difficult to cope with the complicated tasks to master, as skill in the use of media, as well as prevention programs, (with which parents, teachers, and children and 
young people should be introduced ) and all that to achieve the desired coordination and communication. Children and young people, however, now have a greater choice, but following an identity crisis, a weak influence of social values ( unity ), and disorientation in the accelerated development of the technical revolution. Children and young people are increasingly becoming slaves of mass communication, addicted to the internet (social networks, Bloogovima, playing video games ..... ). To an increasing extent the remarkable social depression and isolation of the individual, where the lack of values of empathy and altruism becomes a pedagogical challenge to the theory and practice of education ( Miliša 2007; Previšić, 2009). This raises the question: how to bend the media to improve the function of the socialization process and preventing media manipulation ? (Miliša, 2007). Media pedagogy includes socio- pedagogical, socio- political and socio- cultural analysis of media deals for kids, teens and adults (including those in the third age) and analyze all the aspects of growing up, work, leisure and family life. It refers not only to the fundamental requirements of the socialization of children and youth in the world of media and information and communication technology, but also the ability to use information and to develop media competence. Media pedagogy offers new visions and concepts of social integration and the next dimension, the pedagogical role (Schrob and Hüther, 2005). The next section will show the results of research from practice.

\section{Research Hypotheses}

H1: Teachers and parents with children undercommunicate the use of different media, do not point them to verify the authenticity of the information they learn through the media and do not develop in children a reflexive and critical attitude towards the media information .

H0: There is no statistically significant difference in the perception of the frequency of discussions about media between students and parents .

H0: There is no statistically significant difference in the opinion of students on the frequency of discussions about the media with teachers and parents.

H0: There is no statistically significant difference in the opinion of students and parents about the frequency in which they warn parents of the need to verify the information gathered from a variety of electronic and print media sources.

H0: There is no statistically significant difference in the opinion of students and teachers about the frequency in which teachers warn them of the need to verify the information gathered from a variety of electronic and print media sources.

$\mathrm{H} 2$ : The frequency of use of different types of media affects the creativity of free time for students .

$\mathrm{H} 0$ : There is no statistically significant difference in the frequency of use of different media in a free -time students .

$\mathrm{H} 0$ : There is no statistically significant difference between the students of some schools, due to the manner of use of leisure time .
H0: There is no statistically significant difference in the use of certain media in his spare time between students with regard to the place of residence ( urban-rural).

H0: There is no statistically significant difference in leisure time among students, given the class they attend.

H0: There is no statistically significant difference between students in the use of certain media in their free time, with respect to the class they attend.

H0: There is no statistically significant difference between students in the use of certain media in their free time, with regard to gender.

H0: There is no statistically significant between the students in the use of certain media in free time, given the size of the apartment in which they live.

H3: Through the media influence on the students' opinions on different values.

H0 There is no statistically significant difference in the opinion of students who value the media point out, with regard to the county.

H0: There is no statistically significant difference in the opinion of students on the values of the media most notable, considering the class they attend.

H0 There is no statistically significant difference in the opinion of students on the values of the media most notable with regard to gender .

H0: There is no statistically significant difference in the opinion of students on the values of the media most notable, given the place of residence ( urban-rural ).

\subsection{Research Partipants}

Populations to take charge of research participants are seventh and eighth grade elementary school two towns in Dalmatia - Split and Zadar (in Croatia) and their parents and teachers. Recent research in the world and in our country, in Croatia, the data show that primary school seniors (VII and VIII.), And living in major cities, their free time to spend the most innovative media (mobile, video games, internet: Facebook, Skype ... etc), and to indicate the importance of having a certain status symbol (mobile phones) with which to identify.

\subsubsection{Methods of Data Collection}

For the purposes of the research a questionnaire for students seventh and eighth grades, and the custom of the questionnaire for teachers and parents made up of instruments used in two Swiss studies1.

\subsubsection{Analyses of the Data}

Of statistical methods were used: descriptive data analysis methods (all data are presented descriptively and with the data given links descriptive results with existing similar studies) and inferential data analysis methods.

The procedures of descriptive statistics were applied as follows:

- Calculation of frequency

- Calculate the percentage

- Calculate measures of central tendency (mean, mode) 
- Calculate measures of variability (standard deviation)

- Calculation of the correlation coefficient (Pearson coefficient).

\subsubsection{Descriptive Analysis of Data}

Procedure poll 306 elementary school students, and a random 42 teachers and 92 parents. The total number of respondents $\mathrm{N}=440$ The survey was conducted from October 2011. until February 2012. year.

\section{Interpretation of the Results of Research Students}

In this section, the emphasis is on the analysis of the data obtained empirical research conducted among students. Socio-demographic characteristics: type of school, class, place of residence, age and sex, as well as owning a kind of technology.

Table 1. Descriptive measures of the incidence of ownership and possession of types of technology.

\begin{tabular}{|c|c|c|c|c|c|c|c|}
\hline \multirow[b]{2}{*}{ Cardinal number } & \multirow[b]{2}{*}{ Contents particle } & \multicolumn{2}{|c|}{ It is located in my room } & \multicolumn{2}{|c|}{ Most would have lacked } & \multicolumn{2}{|c|}{ I wish I had / } \\
\hline & & $\mathrm{M}$ & SD & M & SD & $\mathrm{M}$ & $\mathrm{SD}$ \\
\hline 1. & TV & 0.44 & 0.49 & 0.25 & 0.37 & 0.25 & 0.43 \\
\hline 2. & digital Television & 0.39 & 0.48 & 0.19 & 0.41 & 0.19 & 0.39 \\
\hline 3. & Teletekst & 0.45 & 0.49 & 0.20 & 0.36 & 0.20 & 0.40 \\
\hline 4. & DVD & 0.39 & 0.49 & 0.17 & 0.32 & 0.17 & 0.37 \\
\hline 6. & CD-player & 0.54 & 0.43 & 0.18 & 0.44 & 0.18 & 0.38 \\
\hline 7. & MP3 & 0.61 & 0.50 & 0.16 & 0.47 & 0.16 & 0.36 \\
\hline 8. & Magazines for teens & 0.74 & 0.47 & 0.12 & 0.38 & 0.12 & 0.32 \\
\hline 9. & Games: (Playstation, Sega, Nintendo, itd.) & 0.52 & 0.48 & 0.29 & 0.50 & 0.29 & 0.45 \\
\hline 10. & Computer & 0.65 & 0.50 & 0.27 & 0.18 & 0.35 & 0.44 \\
\hline 11. & Internet & 0.63 & 0.43 & 0.35 & 0.30 & 0.18 & 0.47 \\
\hline 13. & Mobile & 0.93 & 0.40 & 0.49 & 0.50 & 0.03 & 0.50 \\
\hline 14. & Books & 0.78 & 0.39 & 0.03 & 0.49 & 0.10 & 0.18 \\
\hline 15. & WEB-cam & 0.50 & 0.40 & 0.10 & 0.44 & 0.45 & 0.30 \\
\hline
\end{tabular}

The largest percentage of respondents possess mobile (93.14\%), and accordingly believe that their highest, (among the listed items) missed phone $(65.35 \%, \mathrm{M}=0.49, \mathrm{SD}=0.50)$ and the Internet $(64.71 \%, \mathrm{M}=0.62, \mathrm{SD}=0.48)$ was found. Concerned by the fact that the last place of what they are missing school books. The highest percentage would like to once again possess, (contemporary) Mobile (96.41\%, M = $0.03, \mathrm{SD}=0.18$ ). It is evident that students very great importance in the electronic media, and more and more children are becoming media. If you are assessed collectively commonly chosen type of technology that most students have in their room, as shown in Figure 1, is determined to be the largest proportion of respondents than the cell phone uses the computer $(64.37 \%, \mathrm{M}=0.65, \mathrm{SD}=0.50)$, the Internet $(62.25 \%, \mathrm{M}=0.63, \mathrm{SD}=0: 45)$ and MP3-player $(60.25 \%, \mathrm{M}$ $=0.61, \mathrm{SD}=0.50)$. The smallest proportion of respondents has in his room digital television $(28.47 \%, \mathrm{M}=0: 39, \mathrm{SD}=$ $0: 48)$ and DVD (39.99\%, $\mathrm{M}=0: 39, \mathrm{SD}=0.49)$.

The following data show the frequency of use of certain technologies in their free time students. Show that the largest proportion of respondents their free time in front of $\mathrm{TV}$ screens $(84.64 \%, \mathrm{M}=5.68, \mathrm{SD}=0.86)$, the Internet $(71.89 \%$, $\mathrm{M}=0: 25, \mathrm{SD}=0: 41)$, reading comics $(49.78 \%, \mathrm{M}=1: 36$, $\mathrm{SD}=1: 36)$ and listening to a CD or MP3's $(48.48 \%, \mathrm{M}=$ $0.12, \mathrm{SD}=1: 38$ ). If we compare the data using the same media on the basis of the analysis of particle monthly minimum percentage of respondents his free time with the internet $(1.42 \%, \mathrm{M}=1.78, \mathrm{SD}=1.23)$ and $\mathrm{TV}$ screens $(1.89 \%, \mathrm{M}=2.18, \mathrm{SD}=0: 48)$, and the highest reading a book $(39.48 \%, \mathrm{M}=2.36, \mathrm{SD}=1: 58)$. Troubling is the fact that only $1.28 \%(\mathrm{M}=1.64, \mathrm{SD}=0.11)$ of patients five times a week reading a book, and $39.97 \%(\mathrm{M}=1.25, \mathrm{SD}=2: 43)$ never read the book. The mentioned Addicted data suggest a worrying fact that more students her spare time with electronic media (computer, internet, PC games), and the less the print media (books, magazine ..). Based on the analysis of the issues ( the doctorate ), owning a cell phone, only $2.61 \%$ $(\mathrm{M}=1.98, \mathrm{SD}=0: 28)$, the share of respondents said they have no cell phone, but there are $85.62 \%(\mathrm{M}=1.23, \mathrm{SD}=$ $1: 32$ ) responded that is extremely familiar with the function of your mobile phone $(\mathrm{M}=1.18, \mathrm{SD}=0: 59)$. The results show that the respondents know how to use the technical tools to mobiles ( use Office applications to go, camera, MMS, etc ), but not on whether they have developed relfeksino - critical awareness in selective selection of the information .

Based on the analysis of questions about the reasons for owning a cell phone, the highest proportion of respondents for network communication ( SMS, MMS) $79.73 \%(\mathrm{M}=$ $1.79, \mathrm{SD}=0.42)$ and to be in the trend ( $68.56 \%, \mathrm{M}=1: 25$, $\mathrm{SD}=1: 56)$. Furthermore, based on the analysis of the question that most people communicate, most respondents answered with peers ( $77.45 \%(\mathrm{M}=21.98, \mathrm{SD}=39.54)$, and at least komunciraju with parents $(8.5 \%, \mathrm{M}=1: 43, \mathrm{SD}=$ 
0.50). These data indicate the lack of communication with parents, which is an important insight into the analysis of the crisis of education

Furthermore, based on the analysis of how these issues is important to have a specific brand mobile phones (Nokia, Samsung, LG, Sony Erickson, LG), 45.42\% share of subjects $(\mathrm{M}=1.70, \mathrm{SD}=0.80)$ believed that they were extremely important to have a brand cell phones, and only $4.76 \%$ of the respondents $(\mathrm{M}=01.08, \mathrm{SD}=0.33)$ is of the opinion that they are not important brand mobile phones.

The relevant or significant data in the table.

Table 2. The information display students' opinions on the role of advertising in modern media (descriptive measures).

\begin{tabular}{llllll}
\hline Nr. & Name of particle & M & Min & Max & SD \\
\hline 1. & Brand is important, & 0.01 & 0 & 1 & 0.11 \\
2. & For more information & 0.54 & 0 & 1 & 0.49 \\
3. & $\begin{array}{l}\text { to improve communication } \\
\text { all those who are promoting }\end{array}$ & 0.36 & 0 & 1 & 0.48 \\
4. & $\begin{array}{l}\text { and advertising is only } \\
\text { important earnings } \\
\quad \text { "face to face"- }\end{array}$ & 0.37 & 0 & 1 & 0.48 \\
5. & $\begin{array}{l}\text { communication } \\
\text { for use in educational or }\end{array}$ & 0.68 & 0 & 1 & 0.46 \\
academic purposes & 0.01 & 0 & 5 & 0.08 \\
\hline
\end{tabular}

Furthermore, based on the analysis of issues that need you use a computer at home? Most respondents said the games: $70.91 \%(\mathrm{M}=01.04, \mathrm{SD}=0: 45)$, to write: $19.60 \%(\mathrm{M}=1.77$, $\mathrm{SD}=0: 44)$, for online communication (SKYPE): $48.36 \%(\mathrm{M}$ $=1.11, \mathrm{SD}=0.23)$ respectively, programming $15.03 \%(\mathrm{M}=$ $1.16, \mathrm{SD}=0.49)$, to calculate $2.61 \%(\mathrm{M}=1: 44, \mathrm{SD}=0: 54)$, opening Bloogova etc. $7.84 \%(\mathrm{M}=1: 54, \mathrm{SD}=1.12)$, to search for information on the Internet: $62.74 \%(\mathrm{M}=1.87, \mathrm{SD}$
$=1.11)$ for the $\mathrm{E}$-mail $26.14 \%(\mathrm{M}=1.15, \mathrm{SD}=0.65)$, and for the use of Facebook and $46.07 \%(\mathrm{M}=1: 56, \mathrm{SD}=0.87)$. The encouraging fact is that kids do, use the computer to obtain information ( $62.74 \%, \mathrm{M}=1.89, \mathrm{SD}=0: 45)$, but the worrying fact is that the largest percentage of respondents used the computer for games $(70.91 \%, \mathrm{M}=1: 47, \mathrm{SD}=0.71)$. Based on the analysis of questions about the frequency of use of computer games, respondents answer: every day $40.19 \%$ $(\mathrm{M}=1.25, \mathrm{SD}=0: 41)$, once a week $25.49 \%(\mathrm{M}=1.16, \mathrm{SD}$ $=0: 56)$, several times a week $1732 \%(\mathrm{M}=1: 45, \mathrm{SD}=0.42)$ and never $16.99 \%(\mathrm{M}=1: 45, \mathrm{SD}=1: 12)$.Furthermore, based on the analysis of the question of who in the family knows the respondents use the computer, the largest proportion of respondents answered: personally: $50.00 \%(\mathrm{M}$ $=1.25, \mathrm{SD}=0: 45)$, mother: $6.20 \%(\mathrm{M}=1.74, \mathrm{SD}=1.64)$, father: $12.74 \%(\mathrm{M}=1.11, \mathrm{SD}=0: 24)$, sister: $10.13 \%$ $(\mathrm{m} 01.34, \mathrm{SD}=0: 17)$ and brother: $20.91 \%(\mathrm{M}=1.24, \mathrm{SD}=$ $0: 41)$.

Based on the analysis of issues related to the purpose of using the Internet, respondents showed the highest percentage said they use it for Facebook $(89.86 \%, \mathrm{M}=1: 45$, $\mathrm{SD}=0.42)$, followed by surfing the Internet $(49.67 \%, \mathrm{M}=$ $1: 41, \mathrm{SD}=0.42)$, and for playing games $(37.90 \%, \mathrm{M}=1.74$, $\mathrm{SD}=1.12)$, chat $(25.16 \%, \mathrm{M}=1: 41, \mathrm{SD}=1025)$, news $(9.47 \%, \mathrm{M}=1.25, \mathrm{SD}=0: 45)$, information search $(31.69 \%$, $\mathrm{M}=1.11, \mathrm{SD}=1.15)$ for Skype communication $(18.62 \%, \mathrm{M}$ $=1: 34, \mathrm{SD}=1.21)$ for webcams $(7,51 \%, \mathrm{M}=1.25, \mathrm{SD}=$ 1.25), MSN (3.59\%, M = 1:43, $\mathrm{SD}=1.25)$, Bloogove-forum $(11.76 \%, \mathrm{M}=1.25, \mathrm{SD}=0: 45)$. These data confirm that the inevitable need to integrate media education into the school curriculum, where according to their, often divergent views, the experts agreed working methods in order to develop (own) media competencies.

Table 3. Descriptive data measures students' opinions on the role of parents in the use of media content.

\begin{tabular}{llllllll}
\hline & Name of particle & How to use (use and understand) & How can it affect & \multicolumn{2}{l}{$\begin{array}{l}\text { How to distinguish the good from the bad } \\
\text { offer }\end{array}$} \\
\hline Nr. & & $\mathrm{M}$ & $\mathrm{SD}$ & $\mathrm{M}$ & $\mathrm{SD}$ & $\mathrm{M}$ & $\mathrm{SD}$ \\
1. & About the books & 0.52 & 0.47 & 0.26 & 0.31 & 0.26 & 0.44 \\
2. & About TV & 0.38 & 0.46 & 0.19 & 0.44 & 0.14 & 0.31 \\
3. & About CDs or DVDs & 0.42 & 0.44 & 0.21 & 0.32 & 0.23 & 0.43 \\
4. & About the Games & 0.36 & 0.48 & 0.19 & 0.33 & 0.19 & 0.34 \\
5. & About the Computer & 0.51 & 0.49 & 0.22 & 0.46 & 0.22 & 0.46 \\
6. & About the Internet & 0.52 & 0.42 & 0.14 & 0.46 & 0.19 & 0.37 \\
7. & About the E-mails (how tu uses) & 0.67 & 0.53 & 0.19 & 0.44 & 0.16 & 0.34 \\
8. & About the Mobile & 0.74 & 0.49 & 0.16 & 0.36 & 0.16 & 0.33 \\
9. & About the Skyp-u and WEB-vams & 0.51 & 0.47 & 0.27 & 0.51 & 0.27 & 0.47 \\
10. & Computer & 0.62 & 0.51 & 0.24 & 0.14 & 0.34 & 0.48 \\
\hline
\end{tabular}

The largest proportion of respondents thinking that most of the parents learned to use the print medium $(77.77 \%, \mathrm{M}=$ $0: 52, \mathrm{SD}=0: 47)$, then the impact of television $(64.70 \%, \mathrm{M}=$ 0.38 and $\mathrm{SD}=0: 46)$, on the Internet $30.01 \%(\mathrm{M}=0: 52, \mathrm{SD}=$ $0.42)$, and on the computer $29.32 \%(\mathrm{M}=0.62, \mathrm{SD}=0.51)$. Thus, the data confirm the lack of media literacy in the mother. Furthermore, the largest proportion of respondents were of the opinion that the parents learned to distinguish the good from the bad offer in books $(64.70 \%, \mathrm{M}=0: 26, \mathrm{SD}=$ $0: 44)$, the Internet $(60.04 \%, M=0: 19, \mathrm{SD}=0: 34)$ about it (52.14\%, M $=0: 34, \mathrm{SD}=0: 48)$, which points to the fact that parents are not sufficiently informed about the different functions of the media and their influence.

Based on the analysis of questions from which the subject is the most learned student / by the media, the largest proportion of respondents opinions: in Informatics ( $45.09 \%$, 
$\mathrm{M}=1: 45, \mathrm{SD}=2: 45)$, followed by the Croatian language ( $43.79 \% \mathrm{M}=1: 54, \mathrm{SD}=1.65)$, and then another class communities $(9.80 \%, \mathrm{M}=1.30, \mathrm{SD}=2: 45)$. These data confirm that continues to teach computer class on the use of new technologies, but not about his ambivalent role. So some media literacy can be adopted, such as the technical and visual, but not the development of professional media competencies. The data indicate the necessity of integrating separate the subject of media education in the school curriculum. Furthermore, if we consider the collective analysis of the issues that the subject and the purpose they have learned about technology, obtained the data that IT $56.20 \%(\mathrm{M}=1: 34, \mathrm{SD}=2: 56)$ teaches them about the pragmatic use of certain media tools (work in Word, Excel ), then the Croatian language $36.60 \%(M=1: 56, \mathrm{SD}=2: 53)$ and SRZ $6.86 \%(\mathrm{M}=1.42 \mathrm{SD}=2: 32)$. Unfortunately, worrisome data suggest that IT ( $39.54 \%, \mathrm{M}=1: 53, \mathrm{SD}=$ $2: 32)$, followed by Croatian $46.60 \%(\mathrm{M}=1: 54, \mathrm{SD}=1: 42)$, the core of $8.82 \%(\mathrm{M}=1: 32, \mathrm{SD}=1.43)$ and seminary $0.65 \%$ $(\mathrm{M}=1: 32, \mathrm{SD}=2: 34)$ insufficient warning of the manipulative role of new media .

Table 4. Descriptive measures of students 'opinions of their parents' familiarity with media that students use.

\begin{tabular}{llllll}
\hline Nr. & Answer & M & Min & Max & SD. \\
\hline 1. & fully meet & 2.57 & 1 & 7 & 1.90 \\
2. & Basically they are familiar & 4.05 & 1 & 7 & 11.40 \\
3. & Largely unfamiliar & 2.91 & 1 & 7 & 1.71 \\
4. & Not at all familiar & 2.78 & 1 & 7 & 1.77 \\
\hline
\end{tabular}

Shows a worrying fact that only $48.69 \%(\mathrm{M}=2.91, \mathrm{SD}=$ 1.71), parents are not familiar with the contents, and an additional $5.55 \%(\mathrm{M}=2.78, \mathrm{SD}=1.77)$ was not familiar with media content with the child faces using a variety of electronic and print sourc. Based on the analysis of the question of how often respondents talk with parents about the content they encounter through various electronic media (TV, Internet ...) and press sources (magazines for young ....) obtained the following percentages: the most in the category sometimes $51.63 \%(\mathrm{M}=2: 45, \mathrm{SD}=2.12)$, often $25.16 \%(\mathrm{M}$ $=2: 32, \mathrm{SD}=1.23)$, never $16.01 \%(\mathrm{M}=2.12, \mathrm{SD}=1.21)$ and still $7.18 \%(\mathrm{M}=1.23, \mathrm{SD}=2.11)$. Is not that an additional reason for the erosion of communication in the family, given that a large proportion of students with parents sometimes or never talk about media deals.

Table 5. Descriptive data measures students' opinions about the frequency of checking media by teachers, parents and peers.

\begin{tabular}{lllllll}
\hline Nr. & Answer & N & M & Min & Max & SD. \\
\hline 1. & Teachers & 306 & 2.03 & 1 & 4 & 0.68 \\
2. & Parents & 306 & 2.92 & 1 & 4 & 1.01 \\
3. & Frend & 306 & 1.89 & 1 & 4 & 0.84 \\
4. & Others & 306 & 1.28 & 0 & 1 & 2.01 \\
\hline
\end{tabular}

Table show that parents often warn $(34.34 \%, \mathrm{M}=2.92$, SD $=1.1)$ than teachers $(14.26 \%, \mathrm{M}=02.03, \mathrm{SD}=0.68)$ on the need to verify the information from the media.
Table 6. Descriptive data measures opinions of students activities and values are represented in the media.

\begin{tabular}{lllll}
\hline Nr. & Name of particle & Min & Max & SD. \\
\hline 1. & Power and Politics & 0 & 1 & 0.42 \\
2. & glory & 0 & 1 & 0.19 \\
3. & riches & 0 & 1 & 0.21 \\
4. & commercials and advertising & 0 & 1 & 0.47 \\
5. & beauty (exterior) & 0 & 1 & 0.27 \\
6. & children and youth irrelevant things & 0 & 1 & 0.49 \\
7. & love & 0 & 1 & 0.37 \\
8. & Have a fun & 0 & 1 & 0.41 \\
9. & Information & 0 & 1 & 0.45 \\
10. & Work and education & 0 & 1 & 0.24 \\
11. & honesty & 0 & 1 & 0.49 \\
12. & sensationalism & 0 & 1 & 0.45 \\
13. & compassion and kindness & 0 & 1 & 0.25 \\
\hline
\end{tabular}

The table shows that the students pretty well diagnose the dominant values are represented in the media: Power and Politics (52.61 \%, M = 2:34, SD = 0.42 ) glory ( $50.00 \%, \mathrm{M}=$ $2: 34, \mathrm{SD}=0: 19)$, wealth $(45,75 \%, \mathrm{M} 2.32, \mathrm{SD}=0: 21)$, advertisements ( $28.75 \%, \mathrm{M}=2.14, \mathrm{SD}=0: 47)$ and beauty ( $22.87 \%, \mathrm{M}=1.23, \mathrm{SD}=0.27$.) Considering the consequences of ( preference ) radical moral relativism in the ( family ) education and the media, in the theoretical part of the thesis, we relied on the results of research of Rimac and associates ( 2004), which provides that in Croatia the least preferred values of altruism and empathy, and most wealth and success. Would we then be surprised that children in this study observed the most prominent themes in the media: power, politics, fame and fortune ? The theory of visible data from the pilot study, the 2004th year, about the values that young people prefer, power and wealth are highly ranked as the most desirable values of young people. Today's generation of children and young people most preferred value of 'identity ' ( to be his own master and deal with what you want ) ( Ilišin, Radin, 2007).

\subsection{Interpretation of the Results of Teacher}

Results show that a higher proportion of respondents spend their free time with television $(47.23 \%, \mathrm{M}=1: 37, \mathrm{SD}=$ $0: 44$ ), followed by reading newspapers ( $39.87 \%, \mathrm{M}=1.22$, $\mathrm{SD}=0: 41)$, with a book $(38,45 \%, \mathrm{M}=1.67, \mathrm{SD}=0.11)$, the internet $(36.12 \%, \mathrm{M}=0: 25, \mathrm{SD}=0.78)$ and the $\mathrm{PC}$ ( $21.10 \%, \mathrm{M}=0.12, \mathrm{SD}=0: 45$ ). If we compare the data of the respondents according to data from students in relation to leisure time, we have noticed that students of $37.41 \%$ over using television and $35.77 \%$ over the internet. Thus, we can conclude that the highest percentage of children spend their free time watching $\mathrm{TV}$ and using the Internet, which confirms that the indiscriminate use of free time students increased use leads to the development of certain media and thus endangers the communication in the family. If we compare the data using the same media, based on the analysis 
particles three days a week, participants spend their free time with your computer $(22.14 \%, \mathrm{M}=2.21, \mathrm{SD}=0.78)$, with glednja DVD $(21.38 \%, \mathrm{M}=2: 15, \mathrm{SD}=4.1)$, followed by reading some of the other things $(18.19 \%, \mathrm{M}=2.25, \mathrm{SD}=$ $1.25)$ and reading newspapers $(14.56 \%, \mathrm{M}=0.89, \mathrm{SD}=$ 1.61) .

If we compare the data using the same media -based particle analysis on a monthly basis, the respondents spend their free time with the internet $(11.27 \%, \mathrm{M}=1.60, \mathrm{SD}=$ $0.64)$, with television $(10.48 \%, \mathrm{M}=1.68, \mathrm{SD}=1.86)$ and by reading books $(9.27 \%, \mathrm{M}=1: 36, \mathrm{SD}=0: 58)$. If we compare the data with the students, it is worrisome that only $1.28 \%(\mathrm{M}=1.64, \mathrm{SD}=0.11)$ students five times a week reads, $39.97 \%(\mathrm{M}=1.25, \mathrm{SD}=2: 43)$ never read the book, and the teacher is the difference of $34.25 \%$ higher. Thus, $38.47 \%(\mathrm{M}=1: 45, \mathrm{SD}=0: 37)$ teachers six to seven times a week, though more often reads a book. show data on teachers' views that often $(37.23 \%, \mathrm{CM}=0: 36, \mathrm{SD}=0: 47)$ warn students to the proper use of certain medijskh content in the field of education. A smaller proportion of respondents are of the opinion that only sometimes $(30.00 \%, \mathrm{M}=0.38$ and $\mathrm{SD}=0.48$ ) were direct pupils to rule the use of different media in performing tasks related to education, while still students argue the opposite. If we compare these data with students who are of the opinion that only $14.256 \%$ of the teachers $(\mathrm{M}=02.03, \mathrm{SD}=0.68)$, suggesting the need to verify the information from the media, we can conclude that teachers are not sufficiently warn students on the proper use of media.The data presented show that only $37.11 \%(\mathrm{M}=$ $0: 36, \mathrm{SD}=0: 46$ ) teachers generally familiar with the content they encounter through a variety of electronic and print media sources, while only $24.45 \%(\mathrm{M}=0: 30, \mathrm{SD}=0: 46)$ were not familiar. It is worrisome that only $22.45 \%(\mathrm{M}=$ $0: 53, \mathrm{SD}=0.50$ ) of the respondents are not familiar with the content. Here confirms that teachers do not have the media competence, which also confirms the hypothesis of the necessity of integration of media education into the school curriculum.

Table 7. Descriptive measures of data on the frequency of alerting teachers to the need for verification of media information for students.

\begin{tabular}{llllll}
\hline Nr. & Name of particle & M & Min & Max & SD \\
\hline 1. & Never & 0.30 & 0 & 1 & 0.46 \\
2. & sometimes & 0.40 & 0 & 1 & 0.50 \\
3. & often & 0.30 & 0 & 1 & 0.47 \\
4. & always & 0.19 & 0 & 1 & 0.40 \\
\hline
\end{tabular}

The data presented show a higher proportion of respondents that almost never warn students of the need to verify the information media $(48.12 \%, \mathrm{M}=0: 30, \mathrm{SD}=0: 46)$, followed by $32.89 \%$ of the respondents think that sometimes warn, while only $7.89 \%$ thinks always warn. If we compare these results with data obtained by the students, it can be concluded that the students feel that though the parents $(34.34 \%, \mathrm{M}=2.92, \mathrm{SD}=1.1)$, unlike the teachers $(14.26 \%$, $\mathrm{M}=03.02, \mathrm{SD}=0.68)$ more attention to the need of checking media information.

\subsection{Interpretation of the Results of Students' Parents}

Results show that a higher proportion of respondents his free time with the internet ( $45.35 \%, \mathrm{M}=1.25, \mathrm{SD}=1.78)$, with the computer ( $\mathrm{M}=0.12, \mathrm{SD}=1: 45)$, watching DVD ( $36.14 \%, 0: 36, \mathrm{SD}=2: 47$ ), television ( $36.14 \%, \mathrm{M}=1: 44$, $\mathrm{SD}=2.18)$ and reading newspapers $(32.14 \%, \mathrm{M}=1.22, \mathrm{SD}$ $=1: 44$ ). If we compare the data of the respondents according to data from the students and teachers in relation to leisure time, we have noticed that teachers are free to spend their time with television ( $47.23 \%, \mathrm{M}=1.37, \mathrm{SD}=0.44$ ), reading newspapers ( $39.87 \%, \mathrm{M}=1.22, \mathrm{SD}=0: 41)$, with a book $(38.45 \%, \mathrm{M}=1.67, \mathrm{SD}=0.11)$, with the internet ( $36.12 \%, \mathrm{M}=0: 25, \mathrm{SD}=0.78)$ and the computer $(21,10 \%$ $\mathrm{M}=0.12, \mathrm{SD}=0: 45$ ), and that students of $37.41 \%$ over using the TV for $35.77 \%$ of the internet in relation to teachers, and to $50.05 \%$ of the TV viewing and for $26.54 \%$ more, as compared to the parents. Thus, we can conclude that the highest percentage of children spend their free time watching TV and using the Internet, which confirms that the indiscriminate use of free time students increased use leads to the development of certain media and thus endangers the communication among family and teachers. If we compare the data using the same media, based on the analysis particles three days a week, participants spend their free time with your computer ( $24.13 \%$ and $22.14 \%$ in parents, $\mathrm{M}=2.21$, $\mathrm{SD}=0.78$ ), with glednja DVDs and TV ( $36.14 \%$ and $21.38 \%$ of teachers, $\mathrm{M}=15.2, \mathrm{SD}=4.1)$ and reading the daily newspapers ( $32.14 \%$ and $14.56 \%$ of teachers, $\mathrm{M}=$ $0.89, \mathrm{SD}=1.61$ ). If collectively we consider these data, we conclude that parents Free Skating time, unlike teachers, spend more to watch TV and DVDs for $17.58 \%$ of reading newspapers. Based on the analysis of the question of how parents have to know the content they encounter children through a variety of electronic (TV, Internet ....) and press sources (magazines for young people ...), only $39.00 \%$ of parents responded that they generally unfamiliar, and $25.56 \%$ are fully familiar with. This confirms that parents are generally unfamiliar $(39.00 \%)$ with facilities encountered through various media, and that this leads to the formation of adequate parental educational style, and more are profiled educational style which lacks communication with your own child. Based on the analysis of the question of how the parents aware of the situation when I was a child (a) at home (in his room), using a computer? A higher proportion of respondents believe that most are not familiar $(67.63 \%, \mathrm{M}=$ $1: 45, \mathrm{SD}=0: 47$ ), and a smaller proportion of respondents believe they are generally familiar $(17.43 \%, \mathrm{M}=1.64, \mathrm{SD}=$ 1.84).

Based on the analysis of questions: Do parents warn children of the need of checking the information gathered from a variety of electronic media (TV, Internet ...) and news sources (magazines for young people ...), a smaller proportion of respondents were of the opinion that only sometimes warns $(11,62 \%, \mathrm{M}=1.97, \mathrm{SD}=0.97)$, often $(19.64 \%, \mathrm{M}=1.97, \mathrm{SD}=0.93)$, and never $(24.68 \%, \mathrm{M}=$ $1.97, \mathrm{SD}=0.83)$. 


\subsection{Inferential Data Analysis}

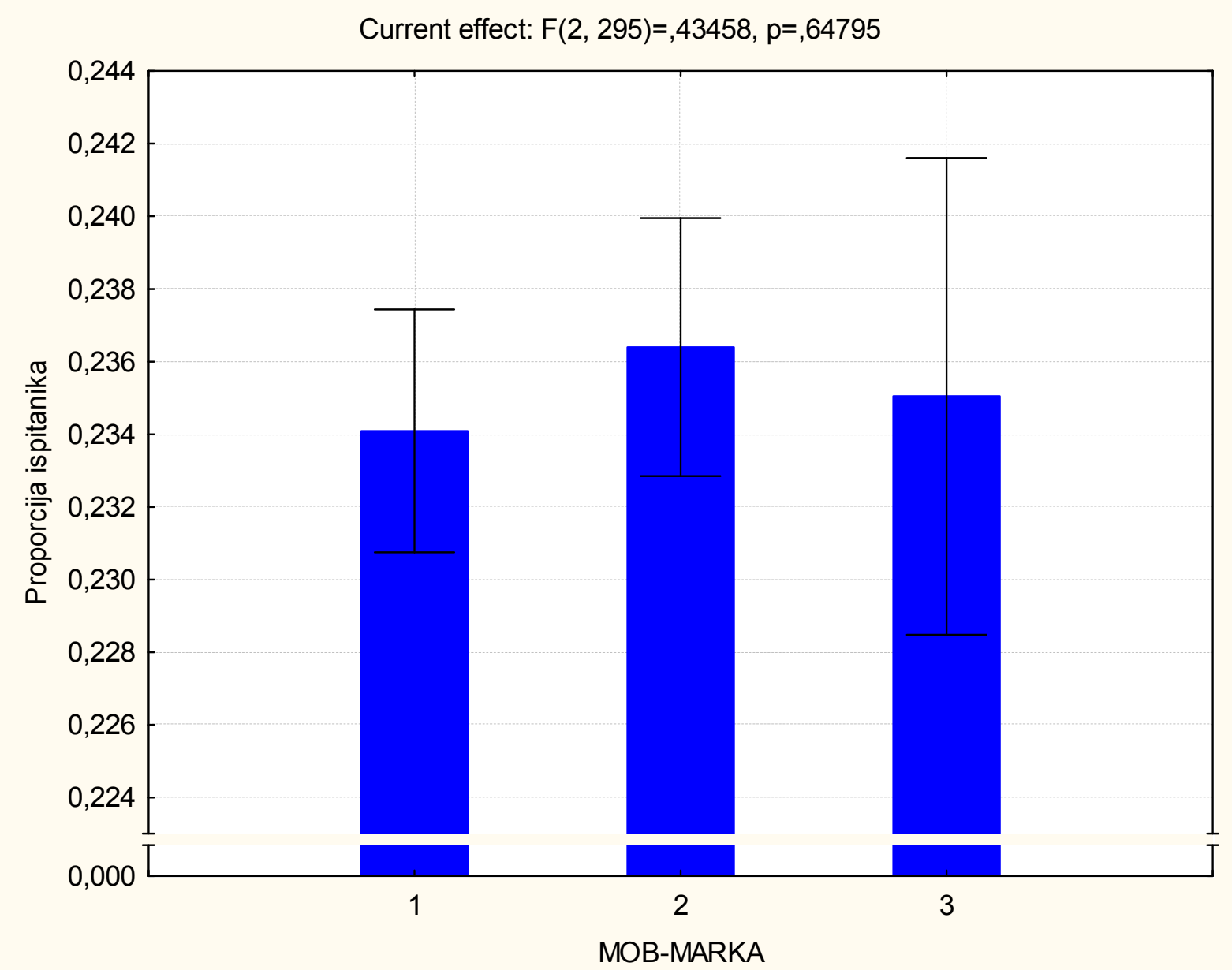

1 - not important brand mobile phones, 2 - very important brand mobile phones, 3 - not at all important brand of mobile phones.

Figure 1. The significance of differences in the number of students who circled the response that is different from the analysis as they have significantly particular brand mobile phones.

Accept the null hypothesis that there is no statistically significant difference in the opinion of students on the possession of a particular brand of mobile phones. At a significance level of $p<0.05$, it was found that there was no statistically significant difference between the students about the importance of cell phone brands $(\mathrm{F}=0.43458, \mathrm{p}=$ 0.64795), as shown in Chart.
Rejects the null hypothesis that there is no statistically significant difference in the opinion of students on the values of the media stand with regard to the response of students on the significance of branded mobile phones. At a significance level of $\mathrm{p}<0.05$ was found that there was a statistically significant difference in the opinion of students on the values of the media stand $(\mathrm{F}=2.3705, \mathrm{p}=0.01)$. 
Current effect: $F(24,1596)=5,2080, p=, 00000$

Include condition: $\mathrm{v} 5=2$

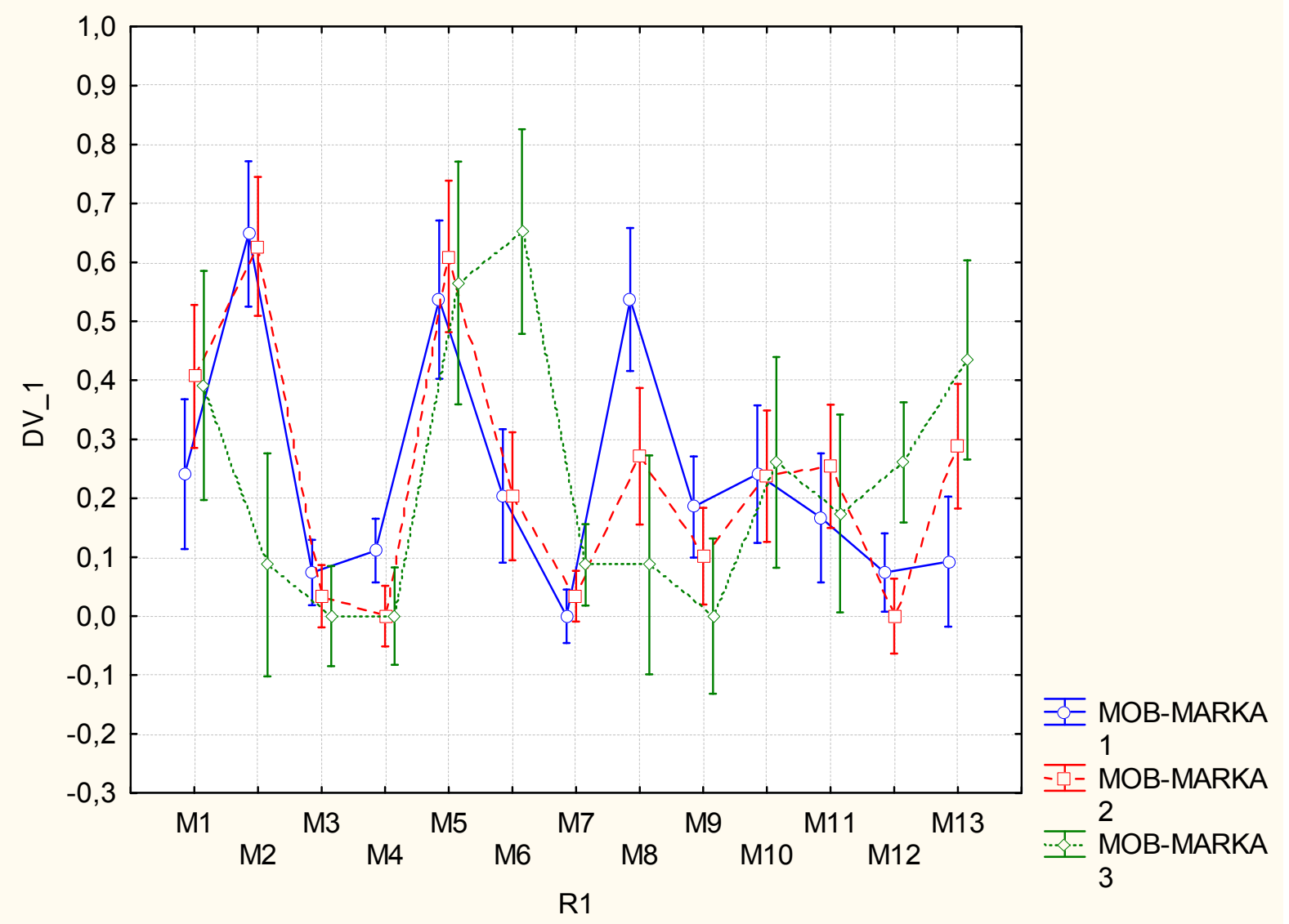

Figure 2. The significance of differences between the opinions of students about the importance of cell phone brands, with regard to male and value - content that the media say.

Legend (X-ordinates): M1: love, M2: Power and Politics; M3: compassion and kindness; M4: honesty; M5 glory; M6: beauty (exterior) M7: Work and education; M8: wealth; M9: sensationalism; M10: fun, M11: information; M12: children and youth unimportant things and M13: advertising and advertising.

Rejects the null hypothesis that there is no statistically significant difference in male students in the perception of the importance of brand mobile phones, given the frequency of opinions we value most prominent media. At a significance level of $p<0.05$ was found that there was a statistically significant difference in male students in the perception of the importance of brand mobile phones, given the frequency of opinions we value most prominent media (1: phone brand: it is not important to me brand mobile phones, 2: brand mobile phones: I'm very important that you have a cell phone brand and 3 mobile phone brand: does not matter to $\mathrm{me})(\mathrm{F}=5.2080, \mathrm{p}=0.00)$, as shown in Chart.

Table 8. Display t-test for Diagram 29 (The significance of differences in the opinions of students on the basis of the analysis of questions as parents and teachers often talk to them about the media content).

\begin{tabular}{lllllll}
\hline & M & SD & N & t & df & p \\
\hline $\begin{array}{l}\text { Talk-parents- } \\
\text { media facilities }\end{array}$ & 2.14 & 0.78 & & & & \\
$\begin{array}{l}\text { Talk-teachers- } \\
\text { media facilities }\end{array}$ & 2.69 & 0.78 & 42 & 3.20 & 41 & 0,002 \\
\hline
\end{tabular}

Rejects the null hypothesis that there is no statistically significant difference in the opinion of students on the frequency of discussions about the media with teachers and parents, which can be seen in Figure 29 and Table 44 At a significance level of $p<0.05$ was found that there was a statistically significant difference in the opinion of students on the frequency of discussions about the media with teachers and parents $(t=-3.20, d f=41, p=.00)$. It was found that students believe that teachers often talk with them about the media. Students think that the parents (as opposed to teachers) often talk about the contents given in the electronic media. Analyzing data from the descriptive analysis, frequency confirmed that teachers almost never talk $(67.51 \%)$ with their students, and parents sometimes talk (15.71\%).

\section{Conclusion}

Media pedagogy sixties has established itself as a separate scientific discipline. It was created as a result of the development of educational sciences and in response to the pedagogical consequences of rapid development (innovative ) 
media and educational technology. It covers the important issues of pedagogical importance of the media in the areas of use of leisure time, education and occupation. Where media reach and grow as a means of information, influence, entertainment, education and the organization of everyday life, that they become the subject of media education. The use of media in everyday life, the need to acquire media competence and the importance of media activity should be directed towards the symbolic exchange between the recipient and the media. While, on the one hand, opening unlimited possibilities of effective cooperation between students and teachers, access to information and lifelong learning, on the other hand, are not only observed primarily as a technical tool in the educational process, but as an aesthetic and symbolic material for self-expression and improve the quality of communication. Based on the analysis set (four) null hypothesis, none of which has not been accepted, accepting the second hypothesis, according to which teachers and parents with children under-communicate the use of different media, do not suggest checking the credibility of the information they learn through the media and do not develop in children reflective and critical attitude towards the media information. Objective ( empirical work) research study was to determine the influence of media messages that are pedagogical implications in the educational process of children in the modern digital technology and society and how they are reflected in the pedagogical practices and determine the difference students' opinions with regard to parents and teachers, as involved in the prevention of media manipulation. In the empirical part of the dissertation in the study included 430 patients, of which 306 seventh and eighth graders, 92 parents and 42 teachers from four elementary schools in Zadar and Split-Dalmatia County. From the results of the research shows that the highest percentage of respondents has a cell phone ( $93.14 \%$ ) and, by analogy, it is considered that they would (again ) the most, ( among the listed items ) missed phone ( $65.35 \%$ ) and internet ( $64.71 \%$ ) and the highest percentage of children her spare time with TV screens ( $84.64 \%)$ and the Internet ( $71.89 \%)$. That the school has lost " race " with the media, implicitly shows ( i) the percentage of the study, which shows that $27.7 \%$ of students / ca only once a month reading reading list ( as mandatory schooling), the highest percentage of students believe that the modern media allow better use of leisure time ( $42.8 \%), 41.8 \%$ of students believe that their important brand mobile phones, in order to be " trendy " and that they care most about peer socialization. The study, therefore, which had set four basic hypothesis is concluded, (based on the above interpreted the null hypothesis) that accepts the first hypothesis is that the media are carriers of symbolic messages, and use different types of media influence on the identification of students with a status symbol .

Accepted the second hypothesis, because teachers and parents with children under- communicate the use of different media, do not suggest checking the credibility of the information they learn through the media and do not develop in children a reflexive and critical attitude towards the media information. Adopted the third hypothesis is that the frequency of use of different types of media influence on creativity of free time for students, and partially accept the fourth hypothesis that through media affects students' opinion about the different values that are most prevalent in the media.

The study showed how the media become the bearers of symbolic messages and what are the pedagogical implications of the no / uncovering and decoding of symbolic messages. Examined the scope of the extent to which teachers and parents contribute to the development of critical use of media, and, analogously, suggest a possible improvement of pedagogical practices to every child the opportunity to become aware of and trained to acquire media competence and their appropriate use. The work proposed by different starting points for greater sensitization of professionals and parents to integrate the subject and content of media education in the modern school curriculum .

\section{References}

[1] Baacke, D. (1997): Medienpädagogik: Grundlage der Medienkommunikation. Tübingen: Niemeyer Verlag.

[2] Hug, T. (2007): Aufwachsen im Medienzeitalter. Überlegungen $\mathrm{zu}$ den veränderten Aufgabenbereichen und Zuständigkeiten der Medienpädagogik. In: Schmidt Siegfried, J. (Hrsg.), Lernen in Zeiten des Internet: Grundlagen, Probleme, Perspektiven. Bozen: Pädagogisches Institut für die deutsche Sprachgruppe, 139-155.

[3] Ilišin, V. (2007): Mediji u slobodnom vremenu djece i komunikacija o medijskim sadržajima, Medijska istraživanja, 9(2), 9-34.

[4] Ilišin, V.; Marinović-Bobinac, A.; Radin F. (2007): Djeca i mediji: uloga medija u svakodnevnom životu djece. Zagreb: Državni zavod za zaštitu obitelji, materinstva i mladeži.

[5] Moser, H. (2000): Einführung in die Medienpädagogik: Aufwachsen im Medienzeitalter. Opladen: Leske und Budrich.

[6] Moser, H. (2006): Standards für die Medienbildung. Schweizer Erfahrungen mit der Entwicklung von Standards. Computer+Unterricht, 63, 16-18.

[7] Moser, H. (200): Standards in der Medienbildung. ein Standardmodell aus der Schweiz. Computer+Unterricht, 63, $49-55$.

[8] Moser, H. (2007): Die Medienpädagogik und der zweite Strukturwandel der Öffentlichkeit. In: Heinz Moser et al. (Hrsg.), Jahrbuch Medienpädagogik 7.: Medeien, Pädagogik, Politik. Wiesbaden: VS Verlag für Sozialwissenschaften, 23-50.

[9] Miliša, Z.; Zloković, J. (2007): Odgoj i manipulacija djecom u obitelji i medijima: prepoznavanje i prevencija. Zagreb: MarkoM.

[10] Miliša, Z; Tolić, M; Vertovšek, N. (2009): Mladi i mediji: prevencija ovisnosti o medijskoj manipulaciji. Zagreb: Sveučilišna knjižara. 
[11] Previšić, V. (2009): Kreativan učitelj- kreativan učenik// VII. Dani Mate Demarina- prema suvremenoj školi/ Matas, M., Vučak, S.; Šagud, M.; Rupčić, S. (ur.) Petrinja: Visoka učiteljska škola u Petrinji, 9-20.

[12] Schorb, B. (1995): Medienalltag und Handeln: Medienpädagogik in Geschichte, Forschung und Praxis. Opladen: Leske + Budrich Verlag.

1 For research purposes, designed the original questionnaire consisted of two questionnaires used in two Swiss study, the team of authors Daniel Suss, Armin Schliengera, Doris Kunz Heim, Markus Basler, Stefan Bohio , Daniel Frischknecht ( 2003), " Jugendlichen und Medien " Merkmale des Medienalltags , unter der besonderer Berücksichtigung Mobilkommunikation ( Forschungsbericht) ( Youth and media - Features media everyday life of young people with an emphasis komukacije mobile, media influence on the socialization of the young generation ), Hochschule für Psychologie angewandete HAP , Fachhochschule ( Abteilung Pädagogik, Zurich and from the questionnaire team of authors : HAP Zurich: Prof. . Dr. Daniel Süss , Dr. Verena Rutschmann, Markus Basler, Stefan Bohio , Corinna Merz , Franziska Mose (2003), Befragung 2003," Kinder und Jugendliche und ihre Medien " ( the slob. translation Young people and their media - the questionnaire ), Hochscule angewandete für Psychologie, Schweizerisches Institute fuf Kinder und Jugendlichen ; Zurich. questionnaires were intended final grades of primary school and early secondary school, and have been used on a representative sample ( $n=667$ second respondents).
[13] Schorb, B.; Mohn, E.; Theunert, H. (2005): Sozialisation durch (Massen-)Medien. In: Hurrelmann, K.; Ulrich, D. (Hrsg.), Handbuch der Sozialisationsforschung. Studienausgabe. Weinheim - Basel, 493-508. 